\title{
SUPRASEGMENTAL SOUNDS PRODUGED BY THE STUDENTS OF ENGLISH EDUCATION DEPARTMENT AT UIN ALAUDDIN MAKASSAR
}

\author{
Nadya Nur azizah \\ Universitas Negeri Alauddin Makassar \\ Nadyanurazizah8@gmail.com \\ Kaharuddin \\ Universitas Negeri Alauddin Makassar \\ andi.kaharuddin@uin-alauddin.ac.id \\ Abdul Muis Said \\ Universitas Negeri Alauddin Makassar \\ abdul.muis.said@uin-alauddin.ac.id
}

DOI: https://doi.org/10.24252/elties.v3i1.19091

\begin{abstract}
This study aims to see the extent the ability of students to pronounce English words who have studied English for many years and studied phonetics, then compare it with the pronunciation of native English speakers. The benefit of this research is that it can increase students' awareness in improving their speaking skills by trying to find new strategies to support their skill improvement. Phonetic and phonology theory is used as concept of this study. The research uses descriptive qualitative method with data collection techniques through recording to retrieve the audio of the samples and native English speaker, then insert it into the gold wave editor to then see the high and low amplitude of the sound. This study focuses on suprasegmental sound especially stress and intonation.The findings of this study showed two things i.e. first, for the stress level, the English students pronounced the words slower and clearer and they also pauses within two words more frequently than the English native speaker and it indicates that the word is stressed with primary or secondary stress. In contrast, the native English speaker pronounced the English words faster than between a word and the coming word and more frequently than the English student. And it indicates that the word is stressed with unstressed (weak stress). Second, the difference of the intonation contour The English native speaker pronounces some words and juncture within two words more frequently, so the intonation contours of her utterances are more falling than rising. On the other hand, English students pronounce the words slower, clearer and gave pause within two words, consequently the amplitude of the words were higher and at the result the rising intonation contour more than falling intonation contour.
\end{abstract}

Keywords : Phonetics, Suprasegmental, Stress and Intonation.

\section{INTRODUCTION}

In Indonesia, English is learned by students as a foreign language and it is mostly dominated in Indonesian Education. It is proven by the fact that Indonesian students learn English from the pre-elementary level up to the university level. Mostly English learners regard English speaking 


\section{Volume 3 Number 01, March 2021}

skills as the measure of mastering English. How good their English depends on how good their pronunciation.

Pronunciation is one of the important aspects, especially in oral communication. Every sound, stress pattern, and intonation may convey meaning. The non- native speakers of English who speak English have to be very careful in pronouncing some utterances or they may create misunderstanding. Because, if a word is pronounced incorrectly, the meaning will be different.

Talking about pronunciation means talking about spoken language by studying its sounds, it is called phonetics (Crane, 1981: 57). Students of the Department of English Education at UIN Alauddin Makassar studied phonetics and phonology in the second semester. Phonetics also describes stress and intonation to help students recognize, understand, and correctly place stress and intonation patterns (Pallawa: 2013).

However, based on the facts of Hartina's (2018) research findings, the researcher concluded that the students of English Education Department 1\&2 intake 2015 at UIN Alauddin Makassar

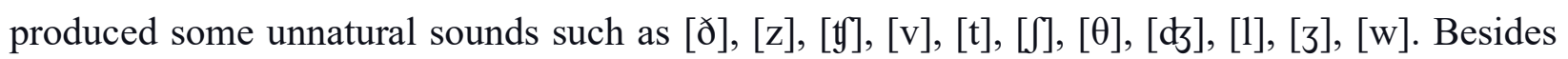
consonants, vowels were produced unnaturally by the students. Those are $[æ],[ə],[\mathrm{I}],[\mathrm{a}],[\varepsilon],[\mathrm{eI}]$, $[\circ],[\Lambda],[\mathrm{ov}],[\mathrm{av}]$.

This study was conducted to determine the extent of the ability of English language education students to produce words, who have studied English at the university level for 7 semesters and also studied phonetics. Theoretically, English students have good skills for passing the various English courses.

This research focused on Suprasegmental sound. Cech, (1983: 36) states that suprasegmental sounds can be interpreted as speech sounds that are extended in several segments. Sunu (2008: 3) states that suprasegmental is related to sound production. These suprasegmental features include tone, stress, intonation, and accent. In this case, the researcher only focuses on two suprasegmental characteristics, namely intonation and emphasis, considering that these two characteristics are important for students to learn, practice, and apply when trying to communicate in English. This is supported by Peter (2009: 36) that stress is important because by knowing the stress in words, we can identify the difference between a noun and a verb. When the word 'import' is pronounced with the first syllable sounding stronger than the second, English speakers hear it as a noun, whereas when the second syllable is stronger it sounds like a verb. Intonation is also important if the word 'true' is spoken in a raised voice, likely to be heard as a question or 
invitation to the speaker, while a lowered tone is more likely to be heard as confirmation or agreement.

\section{Review of Literature}

Related to this research, there are several previous studies. It is presented below:

Hartina (2018) Analysis of English Segmental Sound Phonetics Produced by Students of the English Education Department of UIN Alauddin Makassar. This study discusses the problem of English sound production with special attention to segmental sounds produced by students of the English Education Department of UIN Alauddin Makassar. As a result, Hartina found that students of the Department of English Education class 1 \& 2 class 2015 at UIN Alauddin Makassar made unusual sounds such as $[ð],[\mathrm{z}],[\mathrm{t}],[\mathrm{v}],[\mathrm{t}],[\mathrm{J}],[\theta],[\mathrm{d}],[1],[3],[\mathrm{w}]$. Apart from consonants,

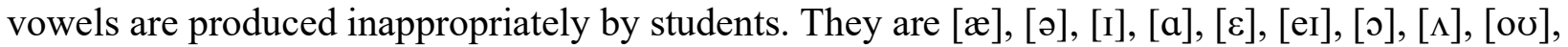
[av].

Arif Rahman Hakim (2012) Phonetic Analysis of b, d, g, j, dz and ð into English Pronunciation for Javanese Students (Study of Javanese Students Department of English at STAIN Bengkulu, 2011-2012 Academic Year). The results of this study indicate that male students in Java are more difficult to get rid of their java stress accent when they speak English compared to female students.

Edadi et all (2017) investigated the Application of Stress, Rhythm and Intonation in Bilingual English Speech. As a result, feature teaching received less attention in the classroom. The introduction of radio and television language programs as well as on-the-job training and teacher retraining in spoken English is suggested to help solve clarity problems among erei students.

Meidy Yuhar Algifari (2016) analized Students' Pronunciation Of Word Stress Of IET 7 Students Of Cambridge English College (CEC) Makassar. This research aimed at analyzing pronunciation skill of the s IET 7 students of Cambridge English College. This research found that there were some misplaced stresses made by the students. The misplaced stress happened to the two-syllable words, three-syllable words, and four-syllable words.

\section{METHOD}

In this study, researcher used a descriptive method. Arikunto (2013: 234) defines descriptive qualitative research as research that aims to collect information about everything that happens in that place according to naturalistic events. 
Volume 3 Number 01, March 2021

\section{Respondents}

The subject of the research was the students of English Education Department $1 \& 2$ intake 2017 which consisted of 42 students at UIN Alauddin Makassar and one native English speaker. The sample of this research consist of 11 students and one native English speaker as the consideration of students' pronunciation.

\section{Instruments}

The instrument took an important role in the research. There are several instruments which are used in this research, such as: Picture Deskription Task, recorder, gold wave editor and native English speaker.

\section{Procedures}

The steps in collecting the data were as follows:

\section{Pre-Recording directions}

At the beginning of data collection, the researcher used the following pre-recording directions to generate speeches and utterance of the respondence of this study. These directions provided in the data collection instruments along with the sentences those given.

\section{Picture Description Task}

After reading all the pre recording directions, the students were allowed to look at the picture shown on the data instrument for at least 60 seconds. The researcher gave a picture, and the researcher asked the student to make a simple sentence. Next, the student had got to start speaking about the picture.

\section{Recording}

While the students speak up one by one, the researcher recorded by using recorder such as handphone.

\section{Transcribing}

After the recording was completed. We listened carefully to the students' utterances then transcribed it. Later, the transcribing of the students' utterances, read by the native English speaker as the consideration of English natural sounds.

\section{Gold Wave Editor}

After that, the researcher analyzed the data that have been collected from recording of sound by inserting into computer. After that, the researcher used Gold Wave to find the characteristic of 
suprasegmental feature produced by the students and compared to those produced by the native English speaker.

\section{Data Analysis}

Based on the research, the researcher, in analyzing the data used the following procedure according to Kaharuddin, and Ismail (2017), analysis refers to four systematic steps:

\section{Collection}

In this first step, the researcher collected the data by recording when the students speak up.

\section{Identification}

After the students utterance the simple sentence, the researcher identified to find out sound quality of suprasegmental features produced by the students compared to native English speaker. The results of analyzing using Gold Wave were in the form of numbers that show the lower and higher intonation, stress frequencies.

\section{Classification}

Next, the researcher classifed the data into two main category. First, the researcher used the level stress such as primary stress, secondary stress and unstressed.The researcher measure the high and low amplitude by using: The amplitude of primary stress $>1.0 \mathrm{~dB}$, while for the secondary stress is $0.4 \mathrm{~dB}$ up to $0.9 \mathrm{~dB}$ and for unstressed is < $0.3 \mathrm{~dB}$. (Verhaar ,1992:30-31). But, because the Gold wave never reaches 1,0 dB, then Sunu (2018) calculates the amplitude as follows: $>0,6 \mathrm{~dB}$ is for primary stress, $0,4 \mathrm{~dB}$ up to $0,5 \mathrm{~dB}$ secondary stress and for unstressed is $<0,3 \mathrm{~dB}$. Second, the researcher used the falling and rising pattern to analyze the intonation of the students' utterances by Kaharuddin and Djuwairiah (2018). In Kaharuddin and Djuwairiah stated that to show how native speaker's utterances and used the pitch levels, linguists record the speakers' utterances and use numbers (intonation contour) to indicate the patterns of intonation. The linguists then establish intonation patterns for normal speeches i.e. falling $/ 2+3+1 /$, rising $/ 2+3+3 /$, and combining patterns $/ 2+3+2+1 /$. We identify a number of different pitch patterns, which convey different meanings:

- Falling Intonation Pattern: $/ 2+3+1 /$

- Rising Intonation Pattern: $/ 2+3+3 /$

- Rising-Falling Intonation Pattern: $/ 2+3+2+1 /$

- Falling-Rising Intonation Pattern: / / $2+1+3 /$

\section{Explanation}




\section{Volume 3 Number 01, March 2021}

The last was explanation. The last step, the researcher explained the main differences between the sound quality of suprasegmental sound produced by the English Education students and native English speaker.

\section{FINDING AND DISCUSSION}

From the analysis of intonation and stress between suprasegmental sounds which are produced by the English students and the native English speaker, it can be found some differences. From there differences, the researcher recognizes the sounds quality between suprasegmental sounds produced by the English students of UIN Alauddin Makassar and native English speaker. The differences of stressing their utterances are in the way how they pronounce their speech.

From the 163 syllables obtained at the stress level, it was found that there were 26 pronounced stresses in students at the primary stress level, 71 in secondary stress, and 66 in unstressed words. While the native English speakers had 16 in primary stress, 57 in secondary stress, and 90 in unstressed.

Then, in the intonation contour, 18 phrases are generated. It was found that students pronounced phrases with various intonation contour variations such as 8 phrases in falling intonations, 5 in rising intonations, 3 in rising-falling, and 1 in falling-rising. As for native English speakers, they are more dominant in pronouncing sentences using falling intonations, this is because native English speakers pronounce sentences quickly, without any pause. Therefore, the result of intonations produced by the native is 16 in falling intonation, 0 in rising intonation, 1 in rising-falling intonation, and 1 in falling-rising.

It can be seen in the charts that the results of the stress level between English students and native English speaker. Native English speaker produce a lot of unstressed sound compared to primary and secondary stress. It is different from the results of the English student charts, which show that it is more dominant to stress some words. So that, it produced higher graphics at primary and secondary stress levels compared to native English speakers.

From the analysis of intonation and stress between suprasegmental sounds which were produced by the English students and the native English speaker, it can be found some differences. The researcher recognized the differences of sounds quality between suprasegmental sounds produced by the English students of UIN Alauddin Makassar and native English speaker, in the way how they pronounced their speech. The difference happened because the English students 
pronounced the words slower and clearer and they also pauses within two words more frequently than the English native speaker. When a word was pronounced slower, the sound would contain a large amount of energy. In addition, the English students paused within two words when they pronounced it, in other word, the energy that they need to pronounce the coming word was higher. When the energy that was needed to pronounce a word was higher, it indicated that the word was stressed with primary stress.

In contrast, the native English speaker pronounced the English words faster between a word and the coming word and more frequently than the English students. When a word was pronounced faster with no pause or juncture, the amount of energy of the sound was lower, it means the amplitude was also low. The lower amplitude of a sound indicates that the word was stressed with unstressed (weak stress).

Next, the difference of the intonation contour between the native English speaker and English students was because of the weak and strong stress of some words. The native English speaker pronounce some words faster, relax and without juncture more frequently, so the intonation contours of her utterances were more falling than rising. On the other hand, English students pronounced the words slower, clearer and gave pause within two words, consequently the amplitude of the words were higher and at the result the rising intonation contour was dominant than falling intonation contour.

The researcher makes chart to reflect each characteristic between the quality of suprasegmental sound produced by the English students and the English native speaker as follows:

\section{The Result Of Students' Sounds In Gold Wave Editor}

Student 1

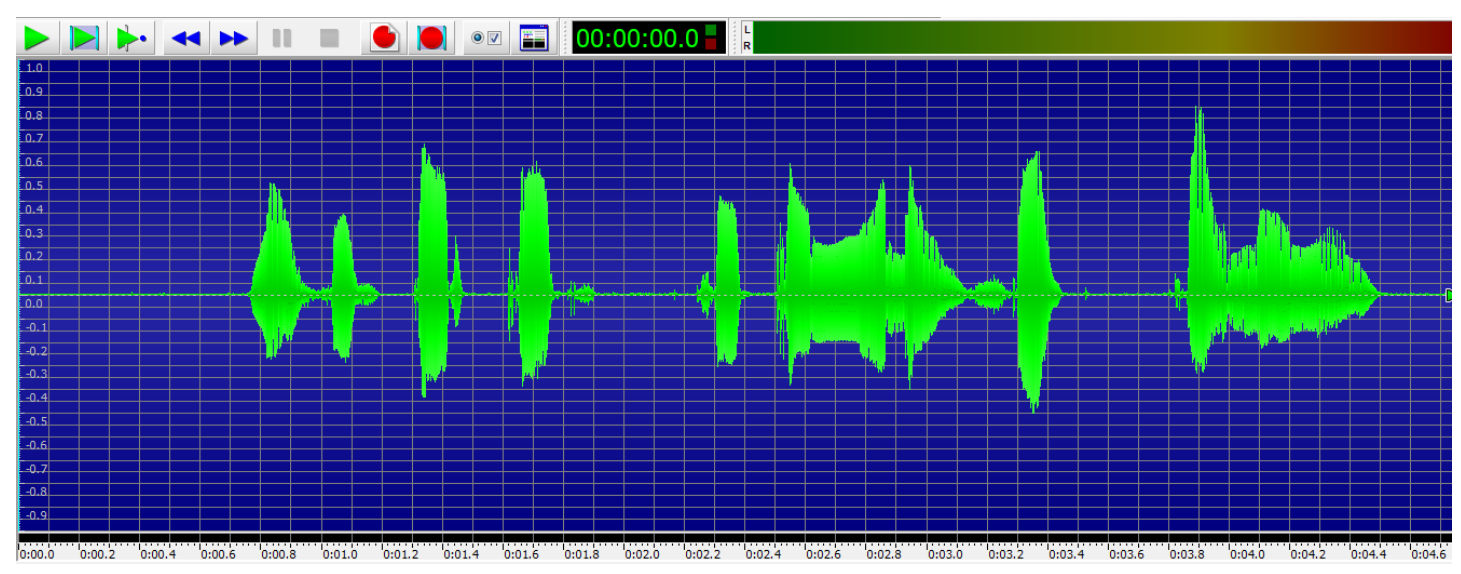




\section{Volume 3 Number 01, March 2021}

My sister cooks chicken noodle soup for dinner.

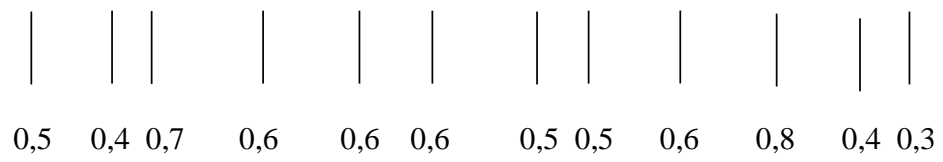

Student 2

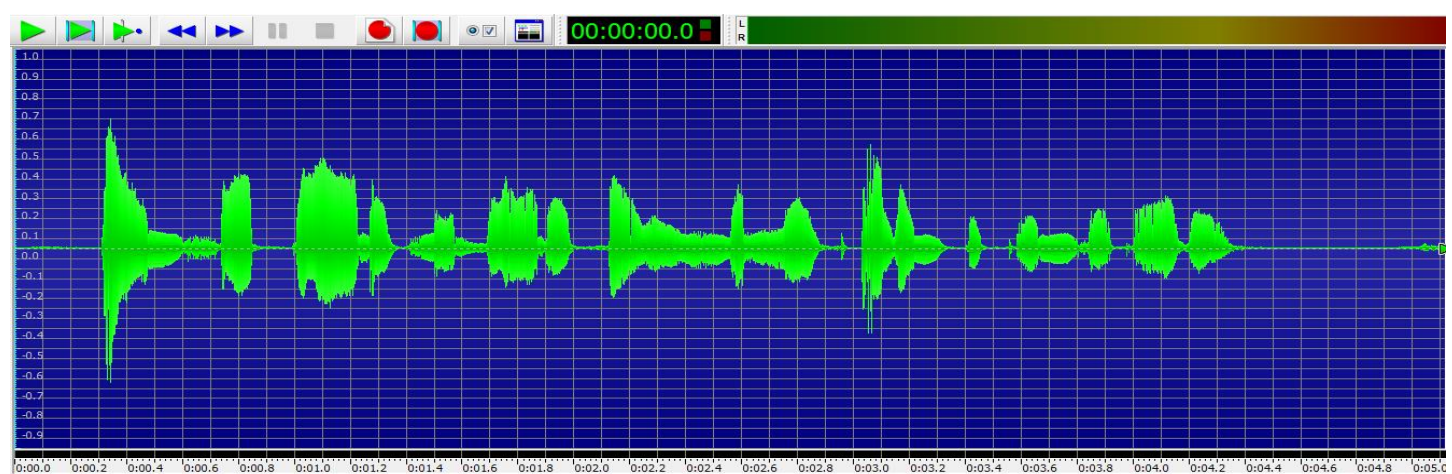

I'm so proud of my brother for winning the math Olympic in Jakarta

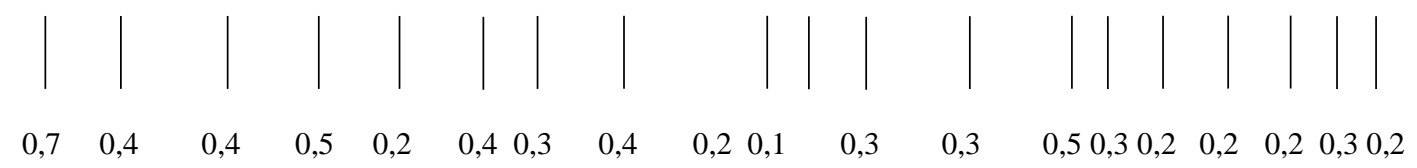

Student 3

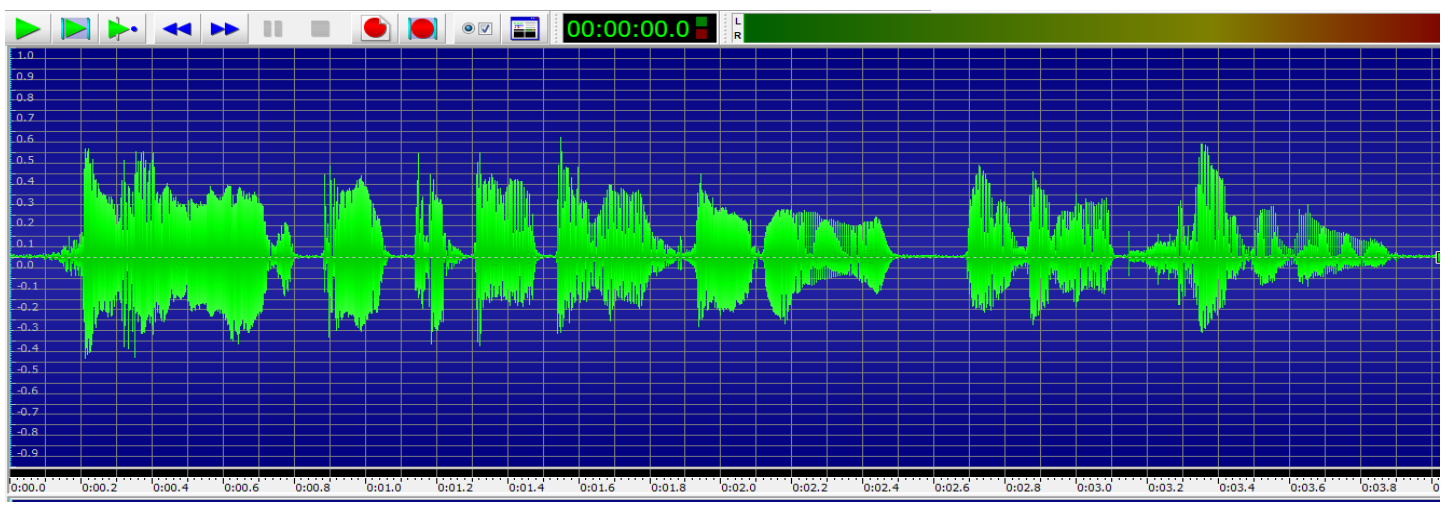

We always talk about our journey on the next holiday

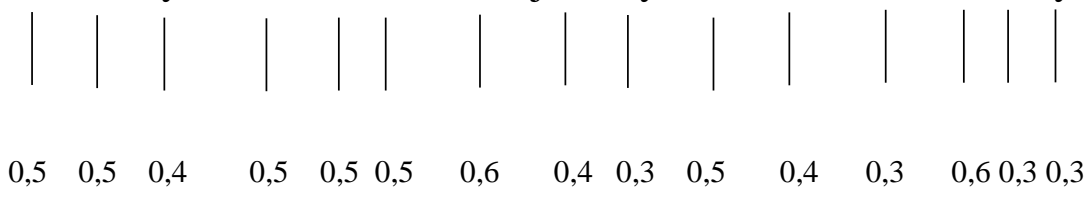


Student 4

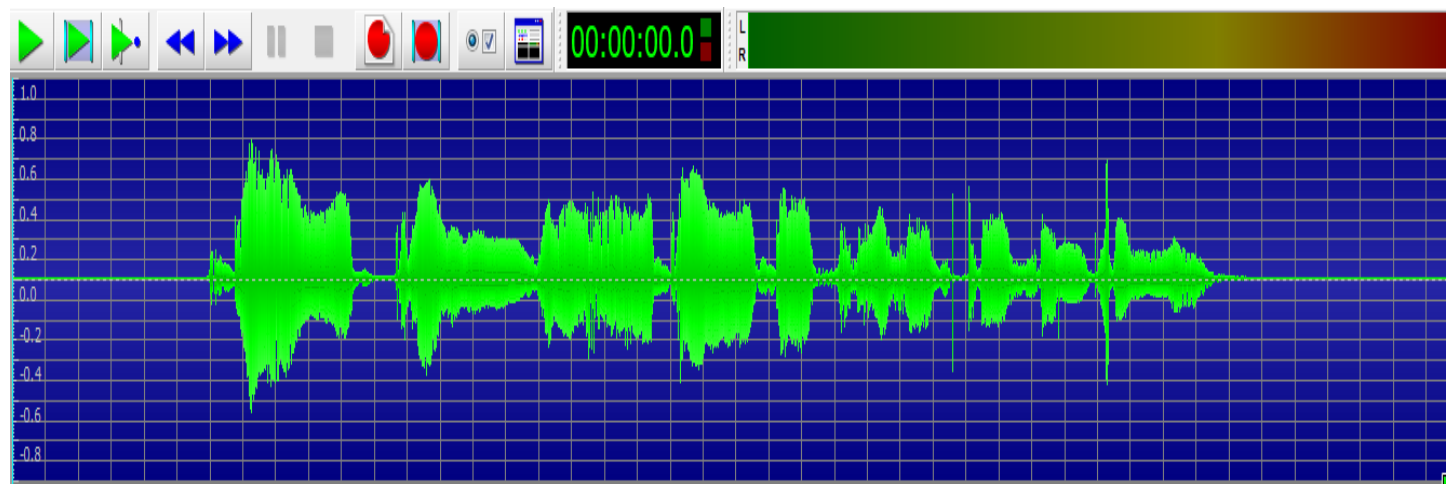

They would drink the water that you have given to me

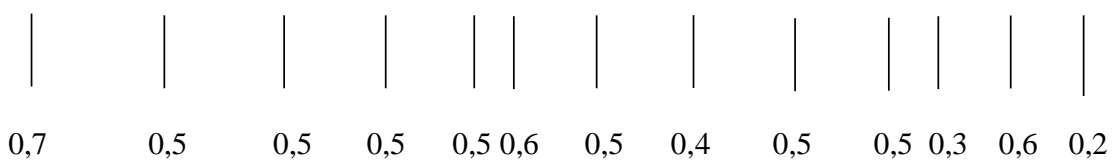

Student 5

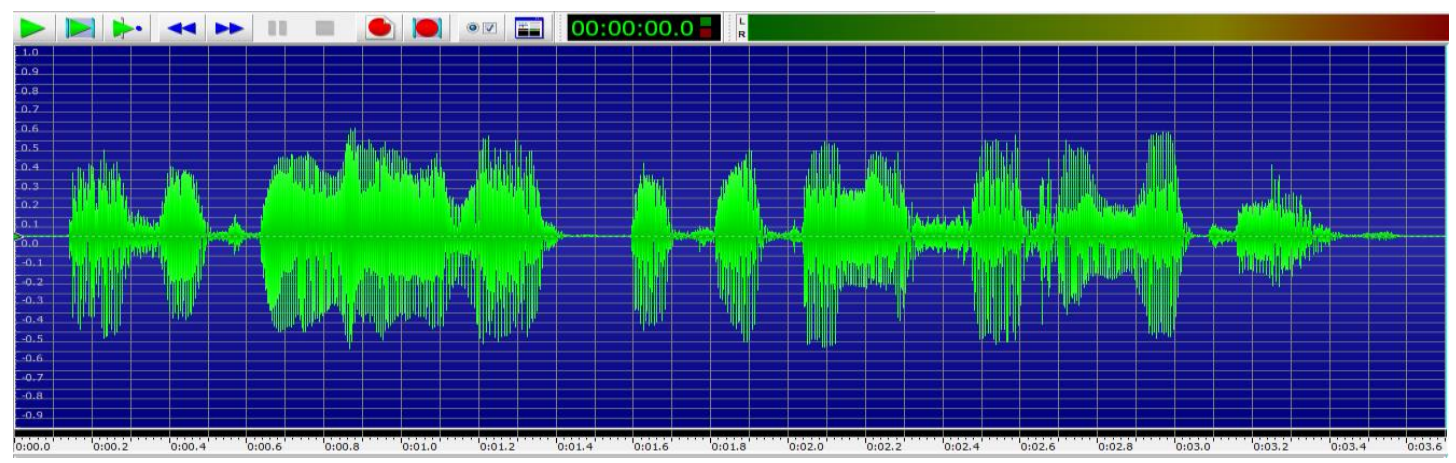

I'll give you a reward if you finish your homework tonight

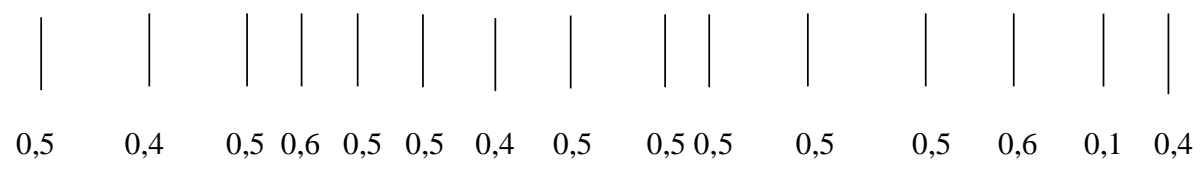


Volume 3 Number 01, March 2021

Student 6

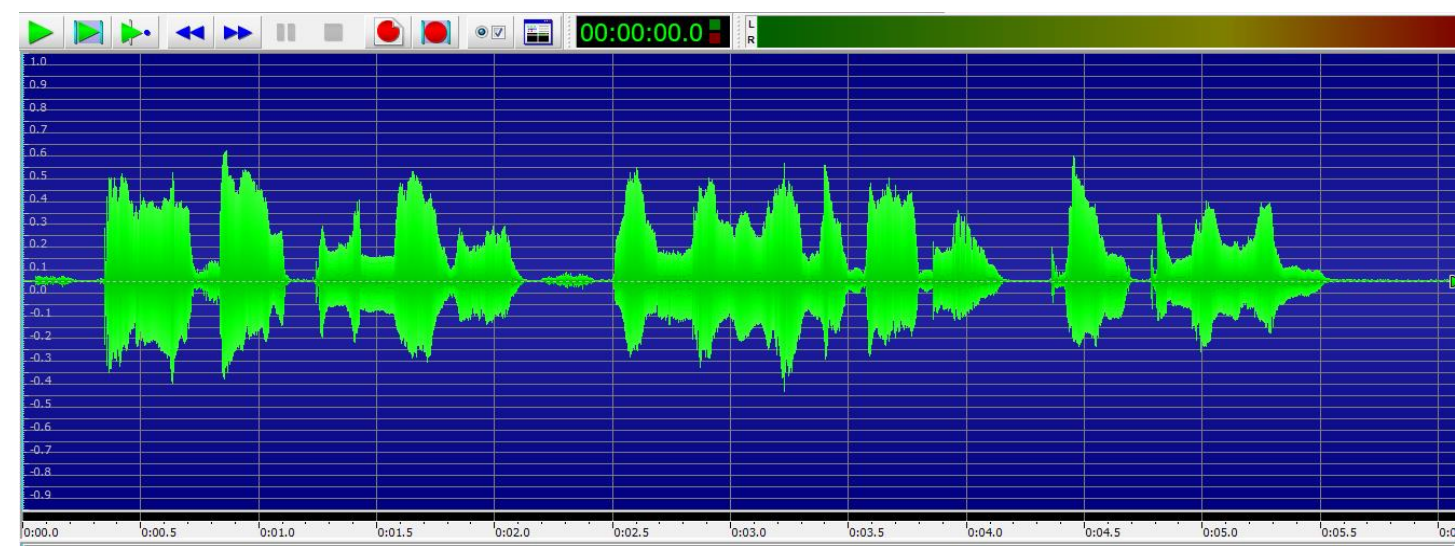

I was writing a novel when my younger brother came to my room

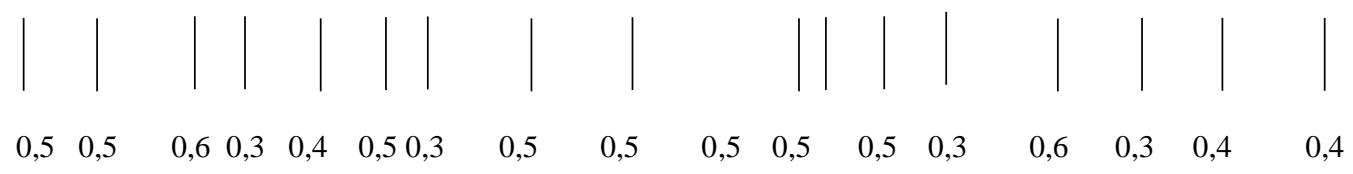

Student 7

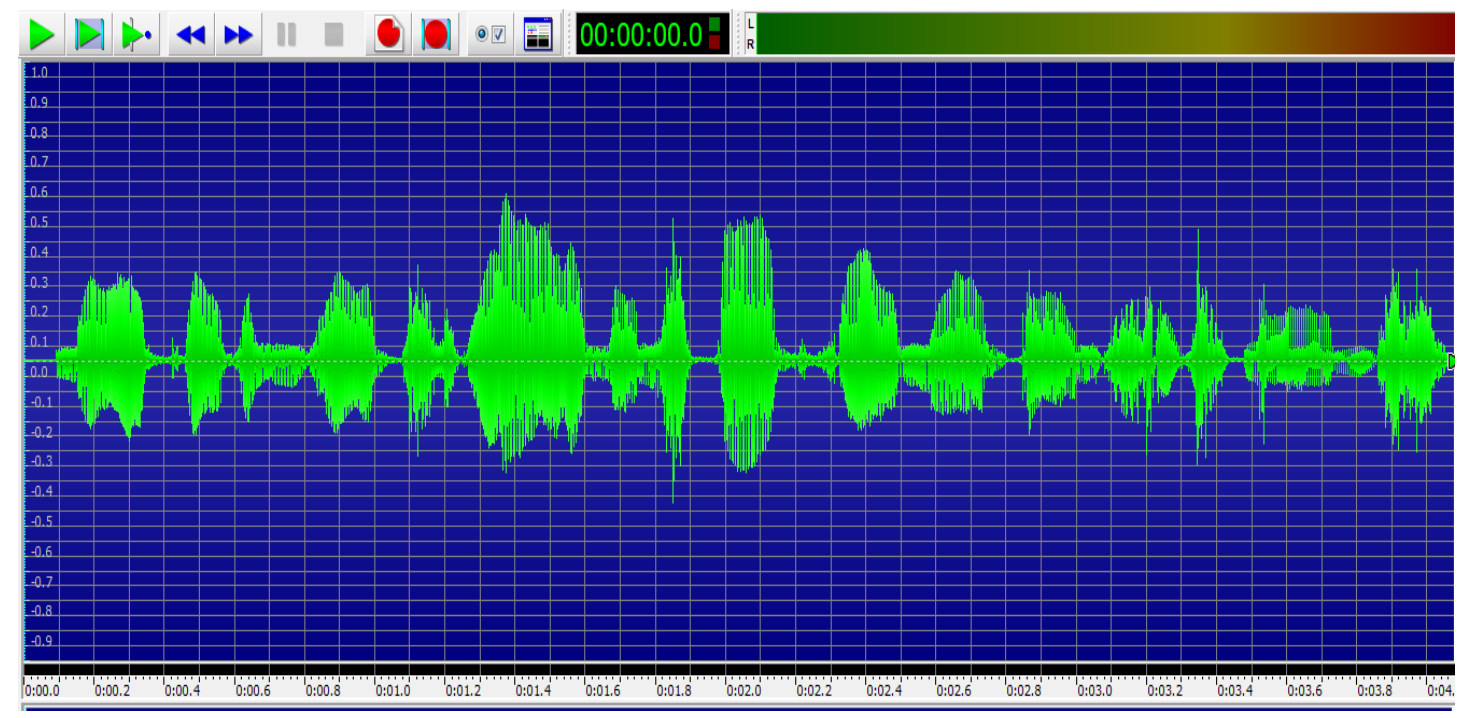

Migrating birds fly nonstop for more than six months

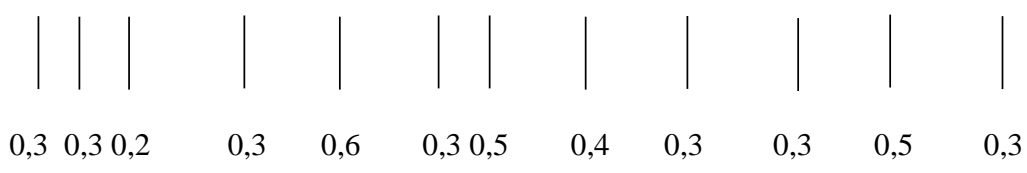


Student 8

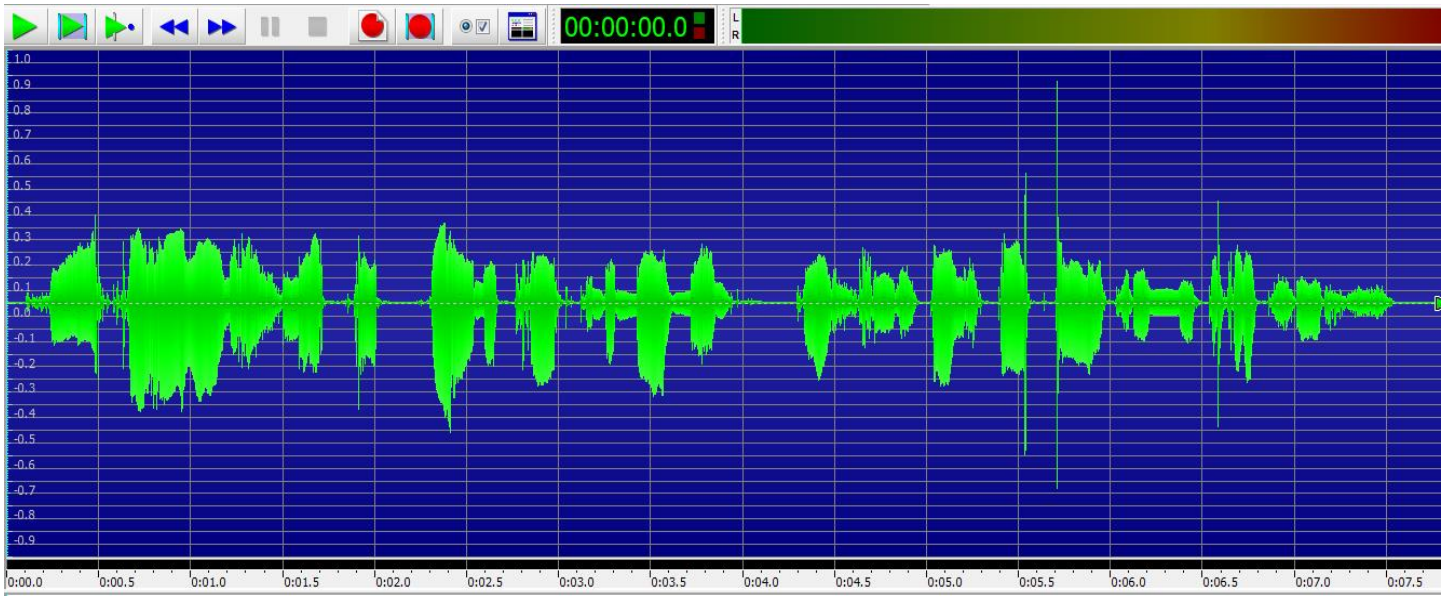

He always sleep at one o'clock in the morning cz he stays up watching Netflix series.

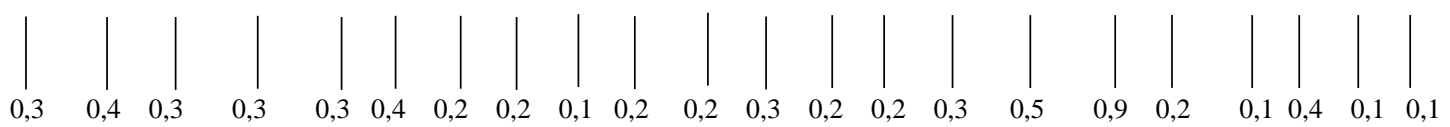

Student 9

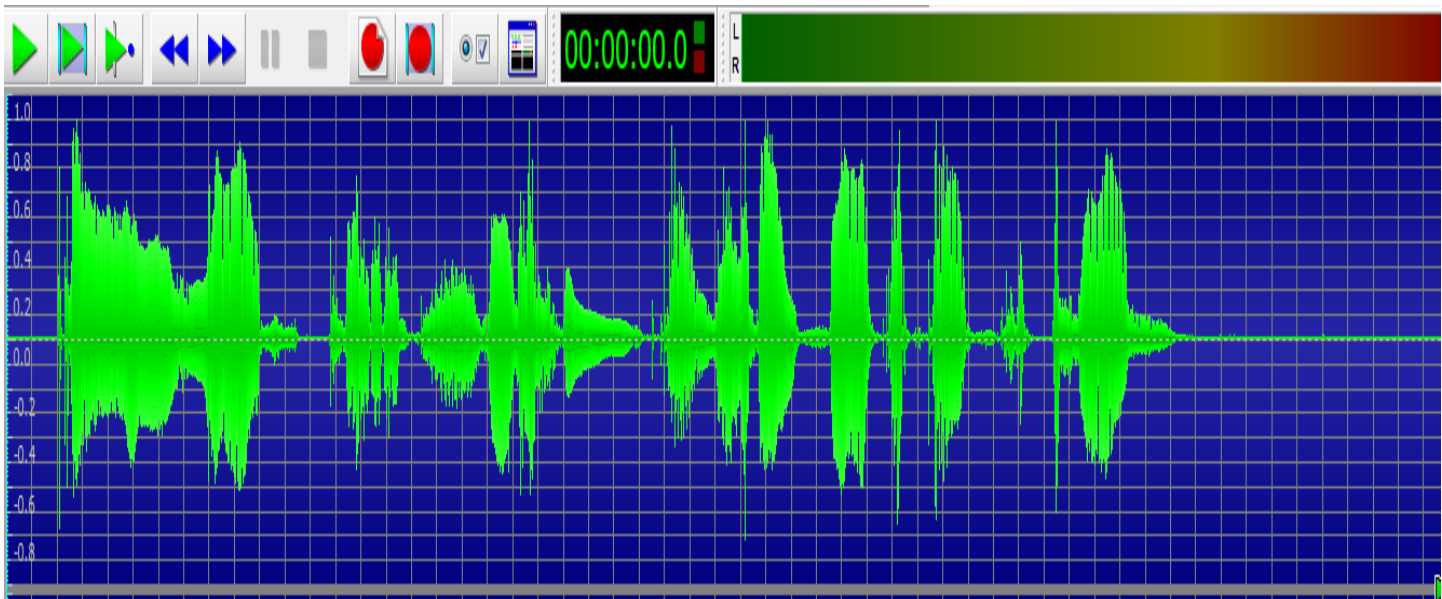

I love to eat sushi and some food of Japan.

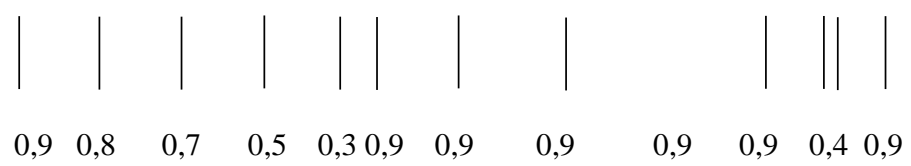


Volume 3 Number 01, March 2021

Student 10

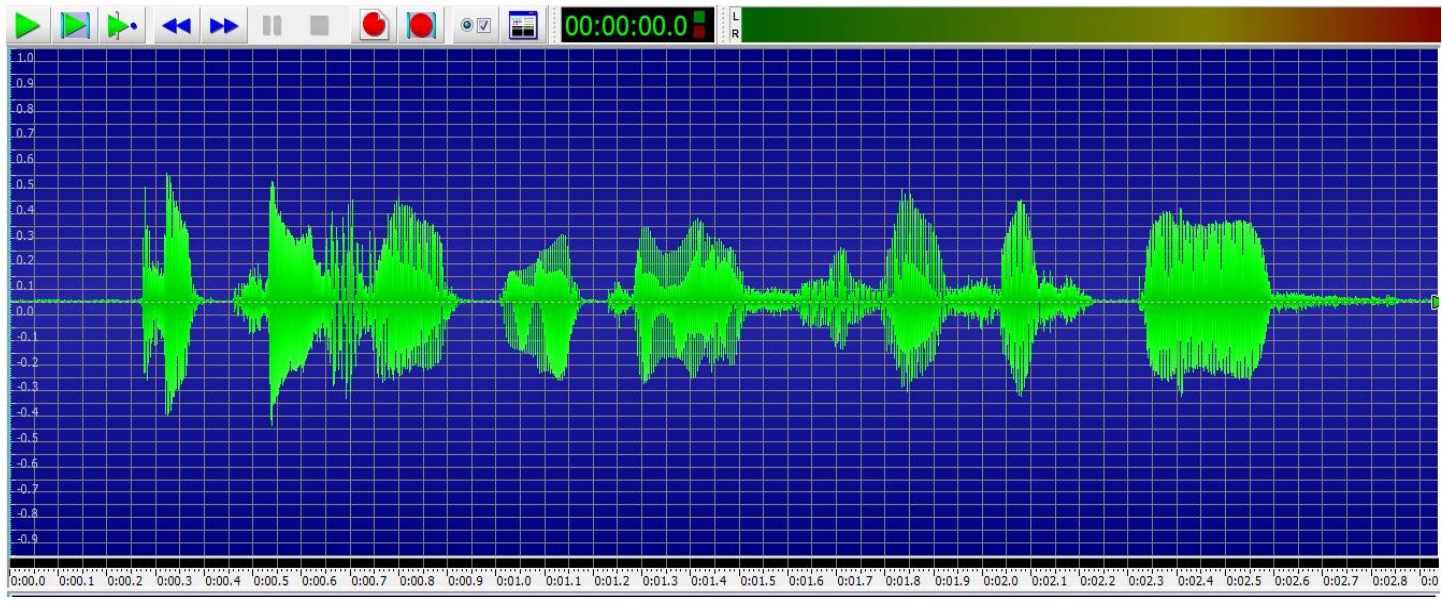

Could you help me to wash the dishes please?

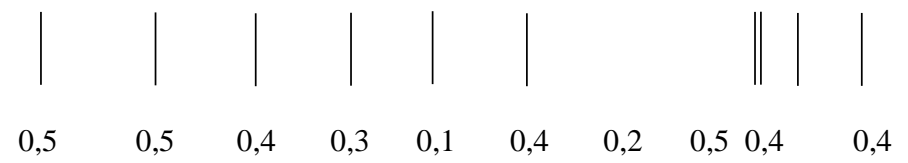

Student 11

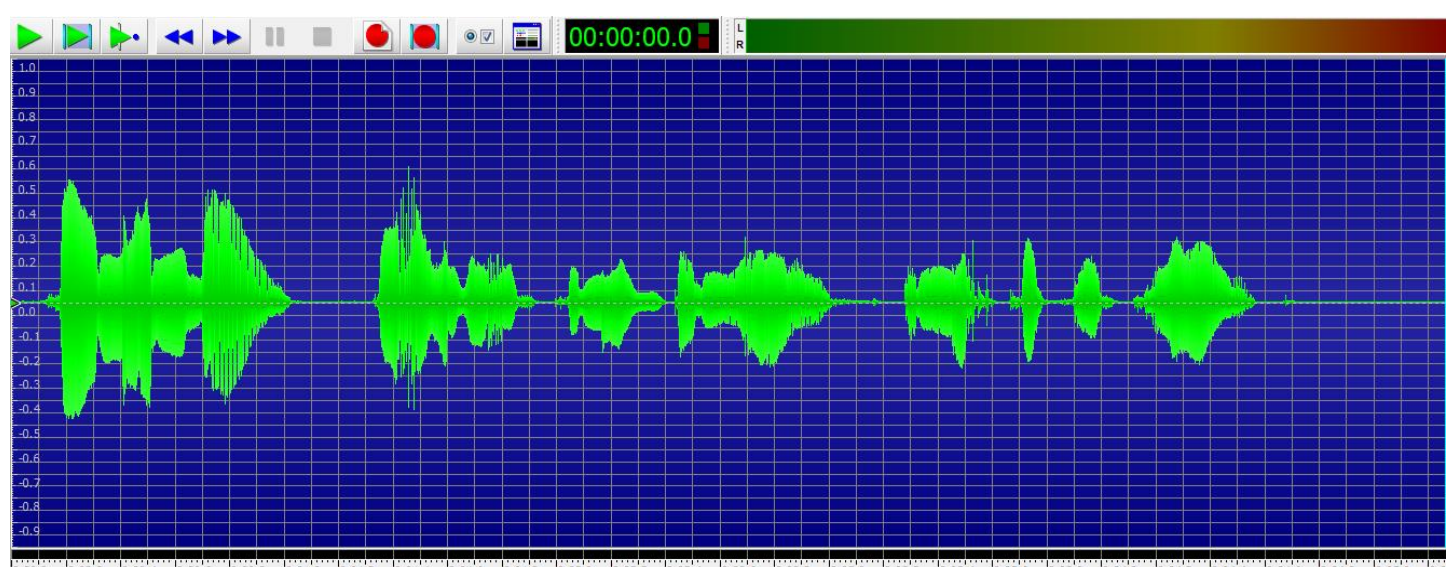

Remember, the idea is to make them laugh and not to frustrate

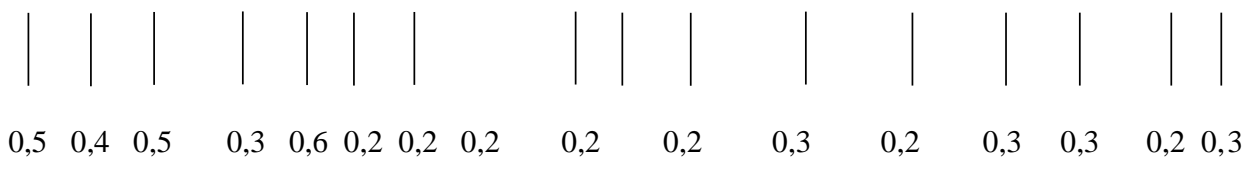




\section{Stress}

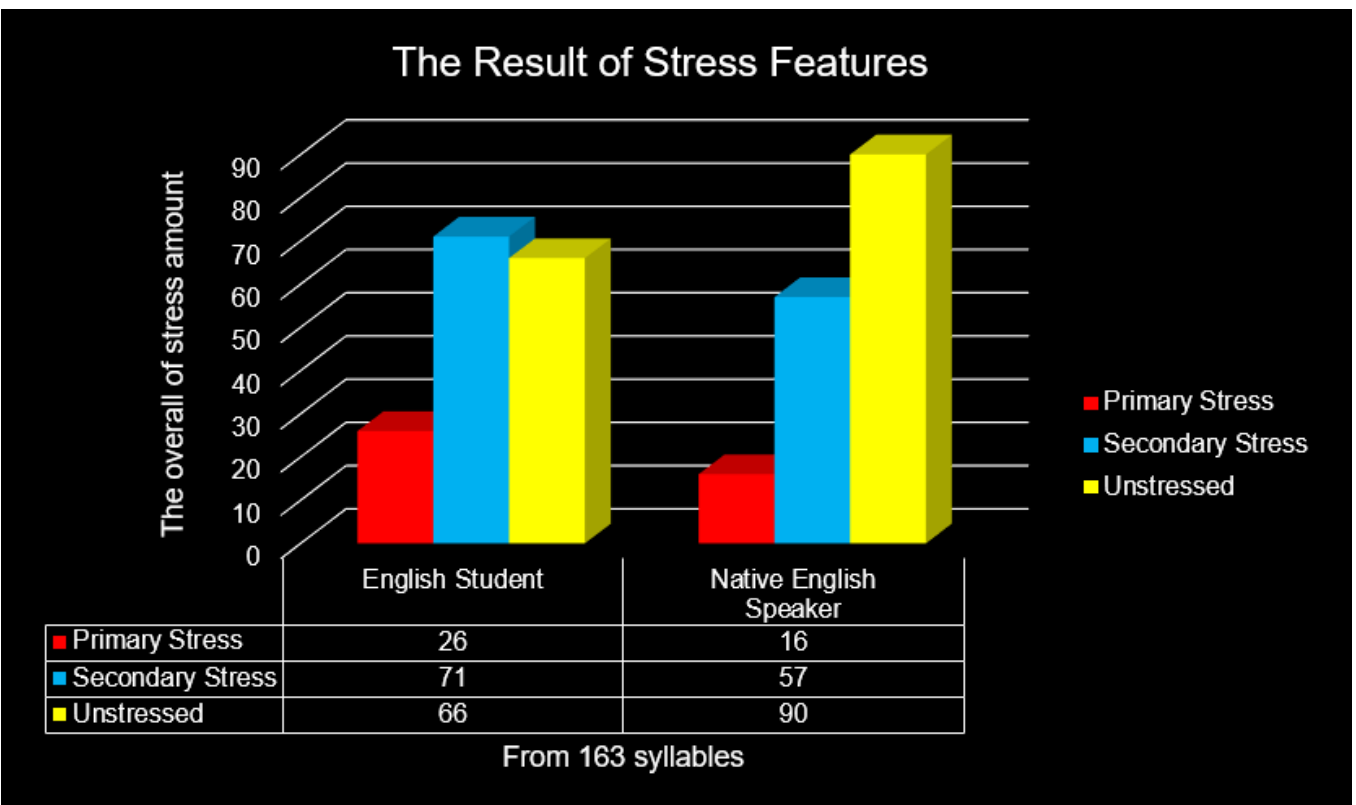

Intonation

\section{The Result of Intonation Features}

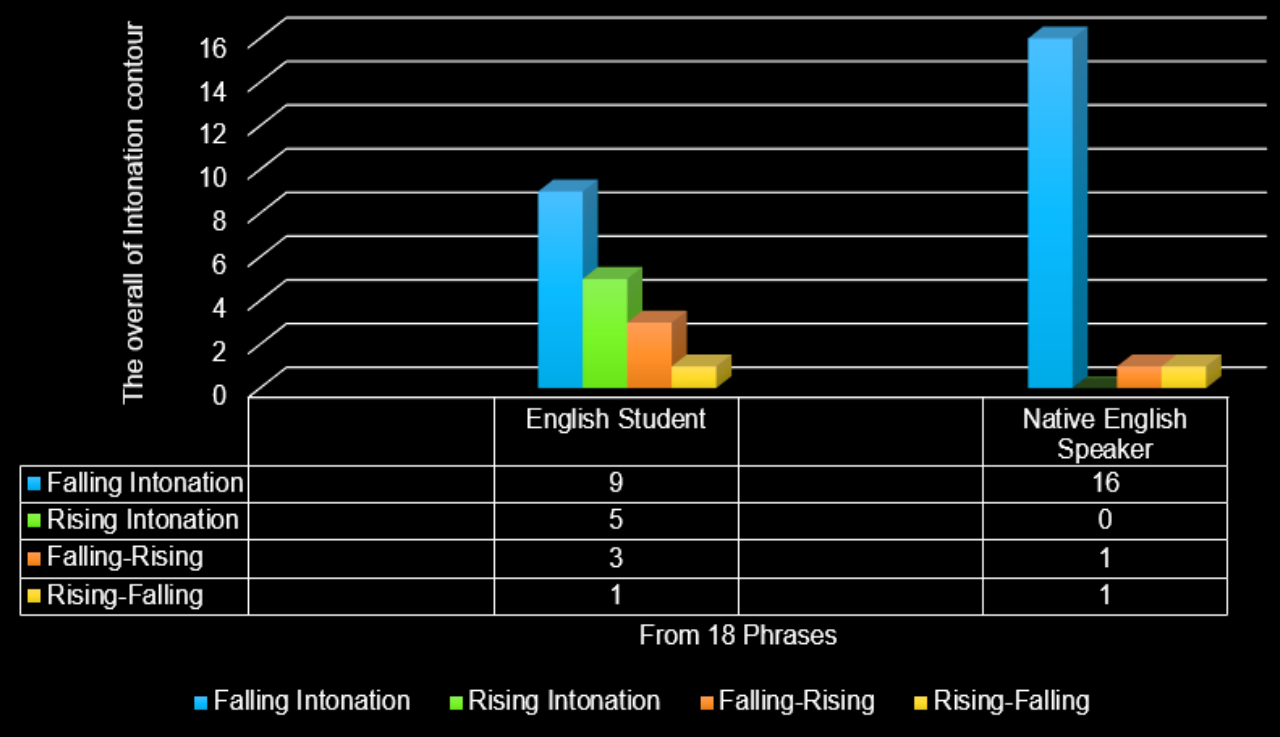




\section{CONCLUSION}

Based on the findings of the research and discussion, the researcher concluded that the sounds quality of English students in pronouncing some sentences is at the lower secondary level because most of them did not have adequate knowledge of how to put stress on syllables of English words and intonation countour of sentences properly. It was supported by Elina Tergujeff (2013), lower secondary level: phonetic symbols was not detected during the utterances or it was indicated that the use of it is rare.

From the analysis of intonation and stress between suprasegmental sounds which were produced by the English students and the native English speaker, it can be found some differences. The researcher recognized the differences of sounds quality between suprasegmental sounds produced by the English students of UIN Alauddin Makassar and native English speaker, in the way how they pronounced their speech.

The difference happened because the English students pronounced the words slower and clearer and they also pauses within two words more frequently than the English native speaker. It indicated that the word was stressed with primary stress. In contrast, the native English speaker pronounced the English words faster between a word and the coming word and more frequently than the English students. It indicates that the word was stressed with unstressed (weak stress).

Next, the difference of the intonation contour between the native English speaker and English students was because of the weak and strong stress of some words. The native English speaker pronounce some words faster, relax and without juncture more frequently, so the intonation contours of her utterances were more falling than rising. On the other hand, English students pronounced the words slower, clearer and gave pause within two words, consequently the amplitude of the words were higher and at the result the rising intonation contour was dominant than falling intonation contour.

\section{REFERENCES}

AMEP Research Centre. (2002). Fact Sheet- What is pronunciation? Retrieved June 9,2019, from http://www.nceltr.mq.edu.au/pdamep.

Arikunto, Suharsimi. Prosedure Penelitian: Suatu Pendekatan Praktik. Jakarta :2013. 
Anngar wulandari et all. 2008. Improving students pronunciation using audio visual aids at the fifth year of al-azhar elementary school of Surakarta in academic year 2007/2008. Kajian linguistic dan sastra, vol. 20 No. 1 Juni 2008.

Ahmed Mohammed Saleh Alduais.2007. Assessing the Importance of Stress and Intonation as Supra-segmental Features of Speech and Sound-attributes to the process of comprehension.

Brinton, Laurel J. 2000. The Structure of Modern English. Amsterdam/Philadelphia: John Benyamin Publishing Company.

Cech, Peter. 2001. Study of Supra segmental features. London: Stanford Bridge University Press.

Celce-Murcia et all. 2010. Teaching Pronunciation.New York: Cambridge University Press.

Creswell, J. (2002), Educational Research: Planning, Conducting, and Evaluating Quantitative and Qualitative Research, Merrill Prentice-Hall, Upper Saddle River,NJ.

Chaedar Alwasilah.2013. Policy On Foreign Language Education In Indonesia. International Journal of Education, Vol. 7 No. 1 Desember 2013.

Crane, Ben, L. and his friends. Introduction to Linguistics.Canada: Little Brown \& Company Boston Toronto, 1981.

Dodd, B., Zhu, H., Crosbie, S., Holm, A., \& Ozanne, A. (2002). Diagnostic Evaluation of Articulation and Phonology (DEAP).

Edadi et all (2017) Application of strees, rythmand intonation in the speech of erei English bilinguals. Global journal of Arts, Humanities and Social Sciences. Vol., No.7, pp.27-38, August 2017.

Hartina.2018. Phonetic Analysis of English Segmental Sounds Produces by The Students of EED at UIN Alauddin Makassar.

Kaharuddin, Andi. and Djuwairiah A. English Phonetics for Indonesia Learners of English. Trust Media Publishing. Yogyakarta. 2018

Kaharuddin, Andi. and Ismail L. The Essential of Discourse Analysis for Teaching as A Foreign Language. Trust Media Publishing. 2017.

M. Arif Rahman Hakim. 2012. An Analysis of Phonetices $b, d, g, j, d z$ and $z$ into English Pronunciation for Java Students (A study On Java Students at English Department on STAIN Bengkulu Academic Year 2011-2012). International Journal of Humanities and Social Science Vol.2 No. 20 [special issue - October 2012).

Meidy Yuhar Algifari(2017) Analyzing Students' Pronunciation Of Word Stress Of Iet 7 Students Of Cambridge English College (Cec) Makassar

Meduna Alexander. Grammar With Context Conditions and their Application. London: Wiley Publications. 2005.

Pallawa, B.A. (2013) A Comparative Analysis between English and Indonesian Phonological Systems, Macrothink Institute, International Journal of English Language Education, 1, 3, 103-129. 


\section{Volume 3 Number 01, March 2021}

Richards, J.C. (2008). Teaching Listening and Speaking: From theory to Practice, New York: Cambridge University Press.

Roach, P. English Phonetics and Phonology. Cambridge : Cambridge University Press. 1983.

Roach, P. English Phonetics and Phonology. Cambridge : Cambridge University Press. 2009.4 ${ }^{\text {th }}$ edition.

Saiful (2008). Word Stress Problems Encountered By Indonesian Speakers In Speaking English.

Sihombing, M. (2014). The Correlation Between The Students' Pronunciation Mastery and Their Ability in Speaking. The Second International Conference on Education and Language (2nd ICEL), 2303-1417. Retrieved from http://artikel.ubl.ac.id (Accessed on, January 5th 2020).

Tergujeff, Elina. (2013). English Pronunciation Teaching for primary, lower secondary and upper secondary level: A mixed methods approach. Retrieved from http://researchgate.net. (Accessed on, December $7^{\text {th }}$ 2020).

Verhaar, J.M.W.1992. Pengantar Linguistik. Yogyakarta: Gadjah Mada University Press.

Widdowson, H.G. 1996. Linguistics. Oxford: Oxford University Press.

Kardaleska, Ljubica. 2006. Contrastive Analysis and Error Analysis in Copmbination with Analysis of the Semantic Level. http://www.sil.org.

Leech, Geofrey\&friends. 2003. An A-Z of English Grammar \& Usage. Malaysia: Longman

Websites:

https://www.efset.org/

http://www.cambridgeenglish.org

https://www.efset.org/cefr/

https://www.coe.int/en/web/common-european-framework-reference-languages/leveldescriptions

https://www.goldwave.com/

https://cambridgeforlife.org/cambridge-english-exam-assessment-resultscert?gclid=CjwKCAiAkan9BRAqEiwAP9X6URACiszURdyvdG_3beHaXBPpdYAAEFGSo7zP1S7dlC5PP5eVyl3NBoC_NEQAvD_BwE 